Nippon Suisan Gakkaishi $\quad$ 59(9), 1551-1558 (1993)

\title{
Expression of the Mature Yellowfin Porgy Growth Hormone in Spodoptera frugiperda 21-AE Cells
}

\author{
Huai-Jen Tsai, ${ }^{* 1}, *$ Hong-Ming Chen, ${ }^{* 1}$ and Chu-Fang Lo*2 \\ (Received March 22, 1933)
}

\begin{abstract}
A complementary DNA (564 base pairs) encoding for the mature region of the growth hormone $(\mathrm{GH})$ of yellowfin porgy Acanthopagrus latus was amplified by polymerase chain reaction. This resultant DNA fragment, ypmGH cDNA, was inserted into baculovirus expression vectors, pAc7, under the control of the polyhedrin promoter. A $22 \mathrm{kDa}$ protein, similar to that of authentic GH, was expressed intracellularly by the insect cell line of Spodoptera frugiperda 21-AE infected by recombinant baculovirus. This protein was reactive with rabbit polyclonal antibodies raised against natural chum salmon GH. Furthermore, a protein band with $22 \mathrm{kDa}$ labeled with $\left[{ }^{35} \mathrm{~S}\right]$ methionine was detected in tha lysate of cells infected with recombinant virus containing ypmGH cDNA. Results from treatment with tunicamycin, an inhibitor of $\mathrm{N}$-link glycosylation, demonstrated that the $\mathrm{N}$-glycosylation did not occur in the recombinant GH produced by this system.
\end{abstract}

The GH cDNA of chum salmon has been cloned and its recombinant $\mathrm{GH}$ (rGH) has also been shown to enhance the growth rate of fish. ${ }^{1)}$ This finding makes GH cDNA potentially useful for the production of $\mathrm{rGH}$ in microorganisms for research and other applications. Thus, GH cDNA has been studied extensively in many species of fish, i.e. chinook salmon, ${ }^{2)}$ chum salmon, ${ }^{1)}$ coho salmon, ${ }^{3)}$ eel, ${ }^{4)}$ gilthead seabream,,$^{5)}$ rainbow trout, ${ }^{, 3}$ red seabream, ${ }^{77}$ tilapia, ${ }^{87}$ tuna,${ }^{87}$ yellowfin porgy, ${ }^{107}$ and yellowtail. ${ }^{11}$ A number of studies of the GH cDNA of these fish focused on expression in either the Escherichia coli system ${ }^{1,4,8,8-10,11,13)}$ or the Saccharomyces cerevisiae system. ${ }^{14-103}$ However, both systems have disadvantages. In the $E$. coli system, the highly expressed products are accumulated within the inclusion bodies in a denatured and unmodified form. ${ }^{17}$ ) It is a complicated and expensive process to renature the rGH before it is ready to be used. In yeast, the construct plasmids in yeast transformants are generally unstable. ${ }^{18)}$

The baculovirus genome offers an alternative expression system for the eucaryotic gene. This interesting gene is ligated in a vector under the control of a polyhedrin promoter, flanked by the viral sequences. The foreign gene with polyhedrin promoter is inserted into the viral genome by homologous recombination in vivo. The resulting recombinant baculovirus is identified by an occlusion negative ( $\mathrm{Occ}^{-}$) phenotype due to the inactivation of the polyhedrin gene. ${ }^{19}$ ) Therefore, this baculovirus expression vector system (BEVS) has recently been reported as an effective approach for expressing eucaryotic genes, since BEVS provides correct post-translational processing. However, using BEVS to express fish genes is limited, except in the case of carp gonadotropin. ${ }^{203}$

The GH cDNA of yellowfin porgy, Acanthopagrus latus, one of the major marine aquacultured fish in Asia, has been cloned from the pituitary gland cDNA library. ${ }^{10)}$ The cDNA consists of 915 base pairs (bp) and encodes a protein of 204 amino acids (aa) including a signal peptide with 17 aa. In the present communication, we will describe how yellowfin porgy GH cDNA (ypGH cDNA) is expressed in insect cells under the control of a polyhedrin gene promoter.

\section{Materials and Methods}

Virus and Cells

The insect cell line of Spodoptera frugiperda $21-\mathrm{AE}$ (Sf21-AE) ${ }^{21}$ ) was propagated at $28^{\circ} \mathrm{C}$ in a spinner culture using a TNM-FH medium ${ }^{22}$ supplemented with $8 \%$ fetal bovine serum. The

*1 Institute of Fisheries Sciences, National Taiwan University, Taipei, Taiwan 106 (蔡 懹槙, 陳 弘民：台湾大学漁業科学䂺究所)。

*2 Department of Zoology, National Taiwan University, Taipe, Taiwan 106 (羅 竹芳：台湾大学䡃物系).

* To whon all correspondence should be addressed. 
wild-type Autographica californica nuclear polyhedrosis virus (AcMNPV) ${ }^{19}$ ) and recombinant virus stocks were grown and titrated in a confiuent monolayer of Sf21-AE cells.

\section{Polymerase Chain Reaction (PCR)}

Two primers, $P 1$ and $P 2$, were used for amplifying GH cDNA without containing signal peptide (ypmGH cDNA). The forward primer (P1), 5'ATGCAGCCGATCACAGACG-3', was encompassed by the nucleotide region from 104 to 119 of ypGH cDNA but was preceded by ATG. The reverse primer (P2), 5'-ATATAAGCTTTTACTACAGGGTGCAGTTGGC-3', was derived by ATAT, HindIII cutting site (AAGCTT) and the antisense strand of one more stop codon (TAA) and the nucleotide region from 667 to 650 of ypGH cDNA. The 915 bp DNA fragment encoding for the full length of ypGH cDNA was used as a template. A reaction in a $100 \mu /$ solution was set up for amplification as described by Innis and Gelfand $^{23)}: 2$ ng of template DNA, $10 \mathrm{~mm}$ of each primer, $10 \mathrm{~mm}$ of each dNTP, $10 \mu \mathrm{g}$ of bovine serum albumin, $10 \mu \mathrm{l}$ of $10 \times$ reaction buffer and 2 units of Vent DNA polymerase (Biolabs). They were mixed and denatured at $94^{\circ} \mathrm{C}$ for $5 \mathrm{~min}$ before DNA polymerase was added. They were treated in a Thermal Reactor (Hybaid, Hook \& Tucker Instruments, U.K.) using the following temperature profile after the first denaturation: annealing at $37^{\circ} \mathrm{C}$ for $1 \mathrm{~min}$ and extension at $72^{\circ} \mathrm{C}$ for $3 \mathrm{~min}$ (1 cycle); denaturation at $94^{\circ} \mathrm{C}$ for $1 \mathrm{~min}$, annealing at $42^{\circ} \mathrm{C}$ for $50 \mathrm{~s}$, and extension at $72^{\circ} \mathrm{C}$ for $80 \mathrm{~s}$ (4 cycles); denaturation at $94^{\circ} \mathrm{C}$ for $50 \mathrm{~s}$, annealing at $60^{\circ} \mathrm{C}$ for $40 \mathrm{~s}$, and extension at $72^{\circ} \mathrm{C}$ for $50 \mathrm{~s}$ ( 25 cycles). Cycling was concluded with a final extension at $72^{\circ} \mathrm{C}$ for $6 \mathrm{~min}$.

\section{Construction of Expression Transfer Vector}

The 580 bp DNA fragment obtained from PCR was ligated into the SmaI site of pUC19. E. coli DH $5 \alpha$ transformants harboring plasmid with the correct polynucleotide sequence of amplifiedDNA fragment were chosen. Sequencing was performed by the chain-termination method of Sanger et al. ${ }^{24}$ ) with a synthesized 13 oligonuclotides primer, 5'-GTCGATGGGGCTG-3', which was complementary to nucleotide position 277 to 289 from the $5^{\prime}$ end of GH cDNA.

The 580 bp ypmGH cDNA produced by PCR was recovered from the pUCGH4 by digestion with EcoRI and BamHI. The resultant DNA fragment was inserted into the corresponding sites of pAcT7, which is a $5.3 \mathrm{~kb}$ of AcMNPV transfer vector. ${ }^{25)}$ The chimeric plasmid construct was designated as pHM4.

Transfection and Isolation of Recombinant Baculovirus

S. frugiperda cells were cotransfected with $1 \mu \mathrm{g}$ of wild-type AcMNPV DNA and $20-30 \mu \mathrm{g}$ of pHM4 using the calcium-phosphate-DNA precipitation method. ${ }^{\left({ }^{3}\right)}$ Plaques produced by each transfection were screened under the microscope for $\mathrm{Occ}^{-}$cytopathic cells. ${ }^{23)}$ The putative recombinant viruses were confirmed by limiting dilution $^{27)}$ and dot blot hybridization ${ }^{28)}$ with digoxigenin labeled ypGH cDNA. Positive clones of luminescence were identified further by $\mathrm{PCR},{ }^{233}$ using one forward primer, 5'-CTATCAATATATAGTTGCTGATATC-3' (primer $3 ;-115$ to -91 of polyhedrin gene) and two backward primers. The latter primers were $5^{\prime}-\mathrm{GG}(\mathrm{T} / \mathrm{C}) \mathrm{GCGTC}(\mathrm{T} / \mathrm{G}) \mathrm{GG}$ (T/C)GCAAA(T/C)TC(T/C)TT(A/T) AC(T/C)TT(A/G)AA-3' (primer 4), which is derived from the antisense from 713 to 682 of polyhedrin gene, and 5'-GTCGATGGGGCTG-3' (primer 5), which is derived from the antisense from 289 to 277 of ypGH cDNA. PCR products were analyzed by Southern blotting, ${ }^{22}$ ) using ypGH cDNA as a probe.

\section{Analysis of Proteins Synthesized by Insect Cells}

Sf21-AE was infected with parental wild-type baculovirus AcMNPV or the recombinant virus containing ypmGH cDNA (AcMNPV-GH4) at a multiplicity of infection (moi) of 10. After $96 \mathrm{~h}$ postinfection, cell cultures were harvested at $500 \times$ $\mathrm{g}$ at $4^{\circ} \mathrm{C}$ and lysed in a sample buffer $(10 \%$ glycerol, $10 \%$ SDS, $5 \%$ mercaptoethanol, $0.1 \%$ bromophenol blue, and $0.5 \mathrm{M}$ Tris- $\mathrm{HCl}, \mathrm{pH} 6.8$ ). Lysate proteins were analyzed by $12 \%$ Sodium dodecyl sulphate (SDS)-polyacrylamide gel electrophoresis (PAGE) ${ }^{303}$ with silver stain ${ }^{312}$ and by immunochemical reaction after Western blot analysis. $^{32)}$ Rabbit polyclonal antiserum against natural chum salmon $\mathrm{GH}$, given by $\mathrm{Dr}$. Thomas T. Chen, the Center of Marine Biotechnology, University of Maryland, was used for the latter procedure since there is $62.4 \%$ homology of amino acid sequence between chum salmon $\mathrm{GH}$ and yellowfin porgy $\mathrm{GH} .{ }^{10}$ ) Goat anti-rabbit IgG conjugated with alkaline phosphatase was used for immunoreaction according to previous procedures. ${ }^{10}$ 


\section{Protein Radiolabeling}

Cells $\left(6 \times 10^{5}\right.$ per well) in 24-well tissue culture plates were infected by virus of AcMNPV or AcMNPV-GH4 separately at an moi of 10 and incubated in $500 \mu \mathrm{l}$ FNM-FH medium at $28^{\circ} \mathrm{C}$ for $60 \mathrm{~h}$. Then the culture medium was replaced by Grace's methionine-free medium (Gibco). Cultures were labeled with $20 \mu \mathrm{Ci}$ of $\left[{ }^{35} \mathrm{~S}\right]$ methionine ( $>1000 \mathrm{Ci} / \mathrm{mmol}$, Amershan) for $6 \mathrm{~h}$. At the end of the labeling period, AcMNPV infected cells, AcMNPV-GH4 infected cells and uninfected Sf 21-AE cells were separately harvested and lysed. Lysate proteins were resolved on a $12 \%$ SDS polyacrylamide gel. After the gel was dried it was exposed to X-ray film (DuPont) at room temperature for $16 \mathrm{~h}$.

\section{Tunicamycin Treatment}

Cells of $3 \times 10^{5}$ per well in 24-well tissue culture plates were infected with AcMNPV and AcMNPVGH4 at an moi of 10 , respectively, and incubated at $28^{\circ} \mathrm{C}$ for $1 \mathrm{~h}$. The culture medium was replaced by $500 \mu l$ serum-free TMN-FH medium ${ }^{33)}$ containing $5 \mu \mathrm{g} / \mathrm{ml}$ tunicamycin (Sigma). After the cells had been cultured at $28^{\circ} \mathrm{C}$ for $4 \mathrm{~d}$, the cells were harvested and their supernatants and lysates were analyzed separately on $12 \%$ SDS polyacrylamide gel with silver staining.

\section{Results}

\section{Construction of Transfer Vector}

A DNA fragment with a molecular weight of 580 bp was obtained from PCR (Fig. 1), which included the $564 \mathrm{bp}$ mature region of GH cDNA. The scheme for plasmid construction is outlined in Fig. 2. The PCR product was ligated in the SmaI site of pUC19. Clones harboring the resultant $3.3 \mathrm{~kb}$ plasmid construct, pUCGH4, were screened. DNA sequencing showed that some nucleotide sequences of PCR-amplified ypmGH cDNA insert in pUCGH4 were 5'-CCCATGCAGCCGATCACAGACGGCCAGCGTCTGTTCTCCATCGCTGTCAGCAGAGTTCAACACCT-3', which was the same as that of the sense strand of ypGH cDNA from 104 to 162 . In addition, it was preceded by CCC (part of the SmaI site) and ATG (an initial codon). The ypmGH cDNA insert was inserted into the pAcT7 and the resultant pHM4 with a molecular size of $5.9 \mathrm{~kb}$ was shown on the agarose gel.

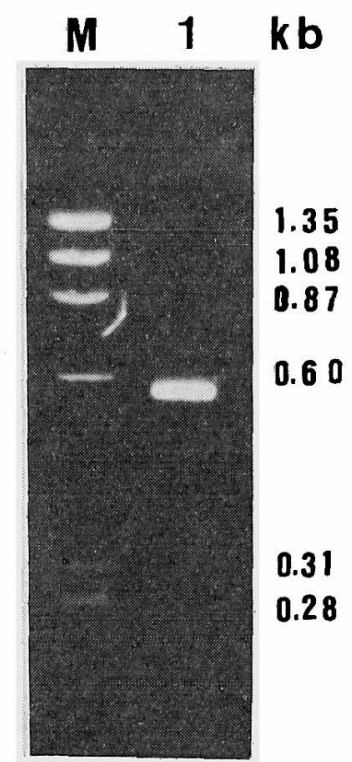

Fig. 1. The DNA product ( $580 \mathrm{bp}$ ) of PCR shown on the agarose gel.

The full length of GH cDNA (915 bp, serving as a template DNA) and two primers (see text) were used to amplify cDNA encoding for the mature region of $y p G H \mathrm{cDNA}$. Lane 1 , PCR product; lane $M$, molecular markers, $\phi \times 174-\mathrm{RF}$ DNA HaeIII digest in kilobase pairs (kb).

\section{Isolation of Recombinant Baculovirus}

After analysis of dot blotting and limiting dilution, one positive cell clone was confirmed to be infected with recombinant virus containing ypmGH cDNA, since its genome generated 0.3 and $1.1 \mathrm{~kb}$ DNA fragments when primers 3 and 4 and primers 3 and 5 were used for PCR, respectively. These two resultant DNA fragments also reacted positively with digoxigenin-labeled ypGH cDNA.

\section{SDS-PAGE and Immunochemical Detection}

Cell lysates prepared separately from Sf21-AE cells, AcMNPV infected cells and AcMNPV-GH4 infected cells were analyzed by SDS-PAGE. A protein band that migrated with an estimated size of $22 \mathrm{kDa}$, similar to that of natural $\mathrm{GH}$, was detected in the sample of AcMNPV-GH4 infected cells (lane 1 in Fig. 3A), whereas this band was absent both in the SF21-AE cells and in the AcMNPV infected cells (lanes $\mathrm{C}$ and $\mathrm{W}$ in Fig. 3A). Immunoblot analysis showed that the $22 \mathrm{kDa}$ protein of AcMNPV-GH4 reacted with 

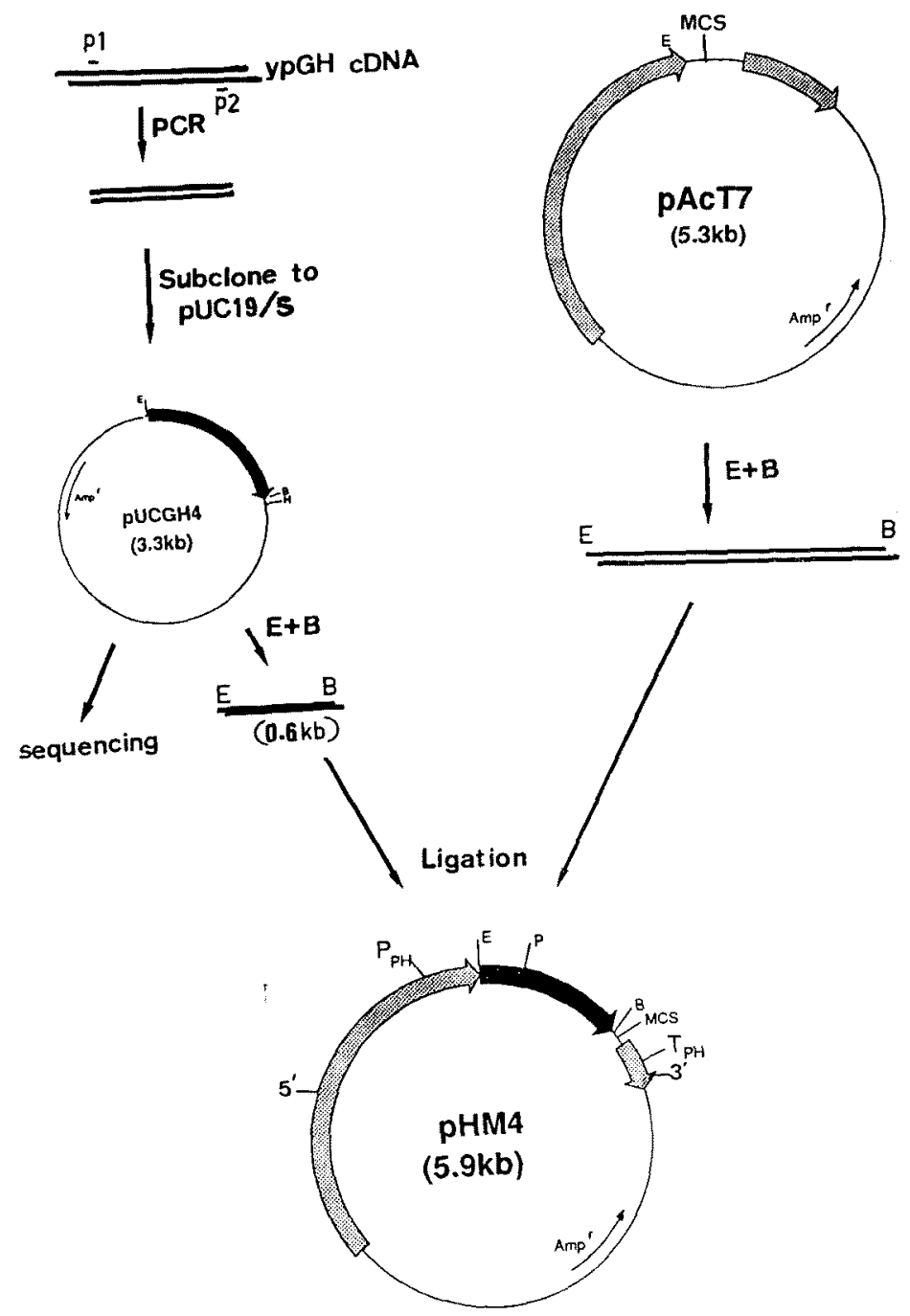

Fig. 2. Construction of plasmid pHM4.

The PCR product (dark shaded box) was ligated into the SmaT site of pUC19. An intermediate plasmid, pUCGH4, was used for partial nucleotide sequence determination. The $5^{\prime}$ - and $3^{\prime}$-noncoding region of polyhedrin $(\mathrm{PH})$ gene are represented by light shaded boxes. Arrows indicate the orientation of genes. Amp ${ }^{r}$, ampicillin resistance gene; B, BamHI; E, EcoRI; S, SmaI; MCS, multiple cloning site; P, Pst ; $\mathrm{P}_{\mathrm{PB}}$ and $\mathrm{T}_{\mathrm{PH}}$, promoter and transcription terminator of $\mathrm{PH}$ gene, respectively.

the chum salmon GH antibody (lane 1 in Fig. 3B). Besides the $22 \mathrm{kDa}$ band, some other bands also reacted with the polyclonal antiserum against the natural chum salmon (Fig. 3B). However, these bands were shared by Sf21-AE cells, AcMNPV infected cells, and AcMNPV-GH4 infected cells.

\section{Radiolabeled Proteins Analysis}

Four major and seven minor polypeptides labeled with [ $\left.{ }^{35} S\right]$ methionine were detected in the lysate of AcMNPV-GH4 infected cells (lane 1 in Fig. 4L). Ten out of eleven labeled protein species were shared between the lysates of AcMNPV infected cells and AcMNPV-GH4 infected cells (lanes 1 and $W$ in Fig. 4L). A labeled 
(A)

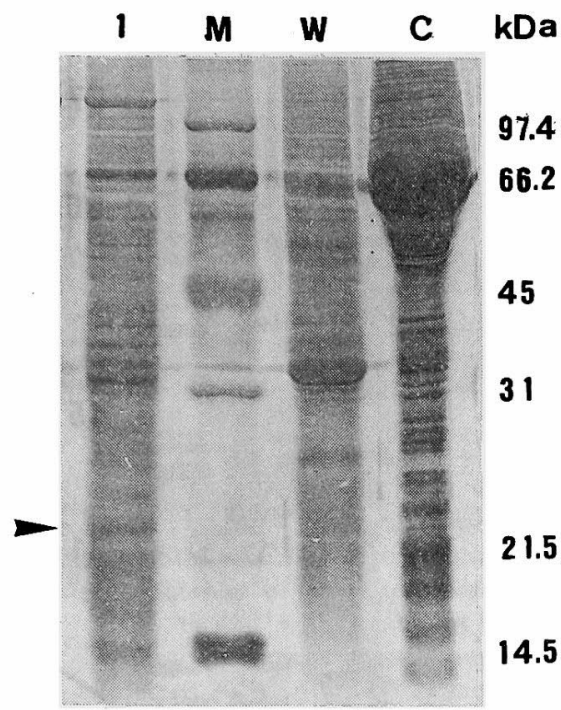

(B)

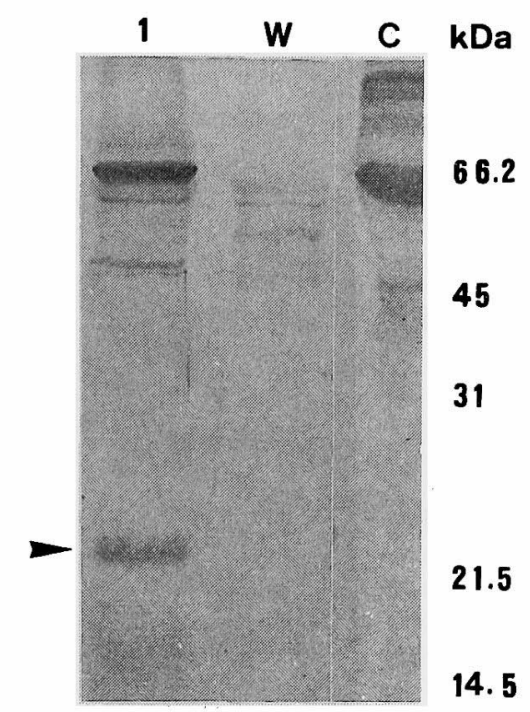

Fig. 3. Analysis of cell lysates by SDS-PAGE with silver staining (A) and by immunochemical reaction with antiserum against natural chum salmon GH (B).

Sf21-AE insect cells (lane C), the parental wild-type baculovirus (AcMNPV) infected cells (lane W) and the recombinant virus (AcMNPV-GH4) infected cells (lane 1) are shown. After $96 \mathrm{~h}$ postinfection, cultured cells were harvested and their lysates were analyzed on a $12 \%$ SDS-PAGE. M, molecular weight markers of proteins in $\mathrm{kDa}$. Arrows indicate the $\mathrm{rGH}$.

band with a molecular weight of $22 \mathrm{kDa}$ was shown in sample of AcMNPV-GH4 infected cells, but was absent both in the Sf21-AE cells and in the wild-type AcMNPV infected cells (lanes 1, W, and C in Fig. 4L).

Proteins in the supernatant of the grown cell culture after $6 \mathrm{~h}$ labeling with $\left[{ }^{35} \mathrm{~S}\right]$ methionine were also analyzed. The result showed that this $22 \mathrm{kDa}$ protein was not detectable in all supernatants of Sf21-AE cells, AcMNPV infected cells, and AcMNPV-GH4 infected cells (lanes C, W, and 1 in Fig. 4S).

\section{Tunicamycin Treatment}

Recombinant $\mathrm{GH}$ band $(22 \mathrm{kDa})$ was shown in the cell lysate prepared from AcMNPV-GH4 infected cells without treating with tunicamycin (lane 3 in Fig. 5). However, this $22 \mathrm{kDa} \mathrm{rGH}$ band did not change its mobility on the gel when AcMNPV-GH4 infected cells were incubated with tunicamycin (lane 4 in Fig. 5).

A structure glycoprotein of baculovirus with a molecular size of $64 \mathrm{kDa}$ was shown on the gel from the lysates of both AcMNPV and AcMNPVGH4 infected cells without treating with tunicamycin (lanes 3 and 5 in Fig. 5). This $64 \mathrm{kDa}$ band, however, decreased to $57 \mathrm{kDa}$ after these cells were treated with tunicamycin (lanes 4 and 6 in Fig. 5).

Recombinant $\mathrm{GH}$ band did not show on the gel from the samples prepared by the supernatants of AcMNPV-GH4 infected cells either with or without tunicamycin treatment (lanes 1 and 2 in Fig. 5), those prepared by the lysates of AcMNPV infected cells with or without tunicamycin treatment (lanes 5 and 6 in Fig. 5), or those prepared by the cell lysates of Sf21-AE with or without tunicamycin treatment (lanes 7 and 8 in Fig. 5).

\section{Discussion}

Results from cell lysate analysis of SDS-PAGE, immunoblotting, and protein labeling showed that rGH with a molecular weight of $22 \mathrm{kDa}$, similar to that of the authentic fish $\mathrm{GH},{ }^{34,85)}$ was 

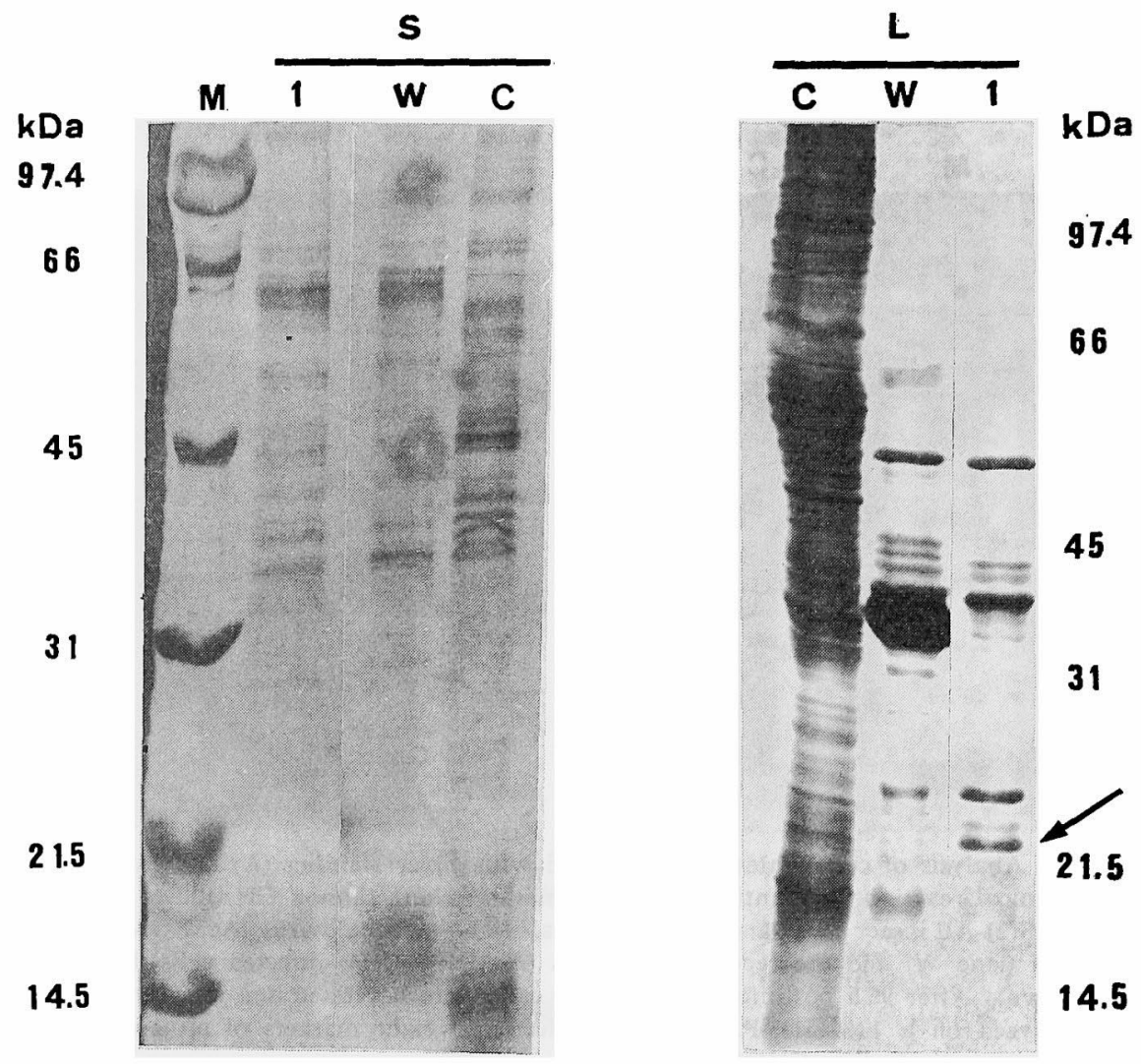

Fig. 4. SDS-PAGE analysis of proteins labeled with $\left[{ }^{35} \mathrm{~S}\right]$ methionine.

Labeled proteins of cell lysates (L) and of the supernatants (S) from the Sf21-AE insect cells (lane C), the parental wild-type baculovirus AcMNPV infected cells (lane W), and the recombinant virus AcMNPV-GH4 infected cells (lane 1) are shown. After labeling, cells were harvested and proteins from the supernatants (S) and from the cell lysates (L) were resolved on the SDS-polyacrylamide gel before they were exposed to $\mathrm{X}$-ray film. Molecular weight markers of proteins are represented in $\mathrm{kDa}$. Arrow indicates the position of $\mathrm{rGH}$ of yellowfin porgy.

expressed by the Sf21-AE insect cells infected with the recombinat virus containing ypmGH cDNA. The maximum expression level of ypGH in this system is $8 \%$ of total cellular proteins. Moreover, the rGH was not secreted from cells infected with AcMNPV-GH4, since the insert GH cDNA in the recombinant virus did not include the codons of 17 aa signal peptide. However, we noticed that if cells were not carefully harvested, i.e. with a higher centrifugation force $(>500 \times \mathrm{g})$, a faint protein band with $22 \mathrm{kDa}$ could sometimes be detected in the supernatant of cell culture (data not shown). This band was also positive immunoreaction. We propose that this detectable band is due to the fact that the
$\mathrm{rGH}$ is released from the broken cells, not because the rGH is secreted from the intact cells.

The most major protein expressed in the late stage of wild-type AcMNPV infected cells was polyhedrin. The intensity of the polyhedrin band shown on the gel appeared to be the highest of all proteins labeled with $\left[{ }^{35} \mathrm{~S}\right]$ methionine (Fig. 4L). In the recombinant baculovirus, the coding region of polyhedrin gene was replaced by ypmGH cDNA fragment. After the recombinant virus infection, however, the expression level of ypGH was significantly less than that of polyhedrin, although the ypGH cDNA and polyhedrin gene were driven by the same promoter. Therefore, we suggest that the structures and characteristics 


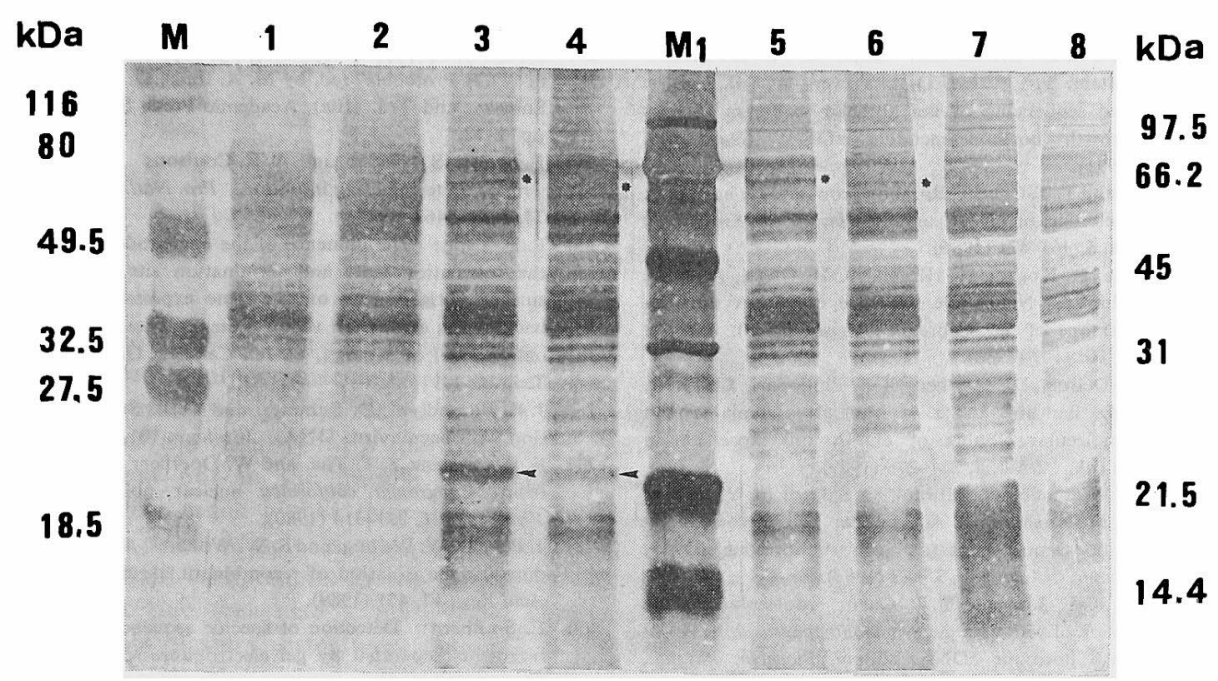

Fig. 5. SDS-PAGE analysis of insect cells cultured with or without tunicamycin treatment. Samples of the supernatants of AcMNPV-GH4 infected cells without treatment (lane 1) and with treatment (lane 2), the cell lysates of AcMNPV-GH4 infected cells without treatment (lane 3) and with treatment (lane 4), the cell lysates of AcMNPV infected cells without treatment (lane 5) and with treatment (lane 6), and cell lysates of Sf21-AE insect cells without treatment (lane 7) and with treatment (lane 8) were shown on the gel after silver staining. $M$ and $M 1$ are the prestained proteins markers and the stained proteins markers in $\mathrm{kDa}$, respectively. Arrows represent the $\mathrm{rGH}$ and stars indicate the protein bands of $64 \mathrm{kDa}$ (upper) and $59 \mathrm{kDa}$ (lower).

of the regulatory region, the immediate upstream of the start codon or even the insert gene per se may be involved in the expression for foreign genes under the control of polyhedrin promoter, as was concluded in previous reports. ${ }^{30-38)}$ To reach an expression level of fish GH cDNA as high as that of the polyhedrin gene may be an interesting subject for future studies.

A structure glycoprotein of $64 \mathrm{kDa}$ located in the envelope of AcMNPV plays an important role in the ability of the virus to enter insect cells. ${ }^{39)}$ This $64 \mathrm{kDa}$ protein band was reduced to $59 \mathrm{kDa}$ in the presence of tunicamycin, an inhibitor of $N$-linked glycosylation, since this glycoprotein loses its sugar moiety. Similar to this report, a $64 \mathrm{kDa}$ protein band occurring in the lysates of AcMNPV infected cells decreased to $59 \mathrm{kDa}$ when the cells were treated with tunicamycin (lanes 5 and 6 in Fig. 5). One potential N-glycosylation site located near the C-terminus, Asn-CysThr, of fish GH has been reported by numerous studies. ${ }^{1,3,5,0,10)}$ However, we demonstrated that the $22 \mathrm{kDa}$ rGH did not change its molecular size in the presence of tunicamycin (lanes 3 and 4 in Fig. 5). Therefore, we propose that the $\mathrm{rGH}$ of yellowfin porgy expressed intracellularly by the BEVS does not undergo glycosylation at this potential glycosylation site. This suggests that the natural GH of fish may not glycosylated. And this could clarify that the $\mathrm{rGH}$ synthesized in $E$. coli is biologically active and has the same potency as natural fish $\mathrm{GH}$, although $\mathrm{rGH}$ is not glycosylated. ${ }^{1,40)}$

\section{Acknowledgments}

This work was supported by the National Science Council, Republic of China, under grant No. NSC 82-0209-B002-487.

\section{References}

1) S. Sekine, T. Mizukami, T. Nishi, Y. Kuwana, A. Saito, M. Sata, S. Itoh, and H. Kawauchi: Cloning and expression of cDNA for salmon growth hormone in Escherichia coli. Proc. Natl. Acad. Sci. USA, 82, 4306-4310 (1985).

2) C. Hew, K. Y. Trinh, S. J. Du, and S. Song: Molecular cloning and expression of salmon pituitary hormones. Fish Physiol. Biochem., 7, 375-380 (1989).

3) L. I. Gonzalez-Villasenor, P. J. Zhang, T. T. Chen, and D. A. Powers: Molecular cloning and sequencing of coho salmon growth hormone cDNA. Gene, 65, 239-246 (1988).

4) A. Saito, S. Sekine, Y. Komatsu, M. Sato, T. Hirano, and S. 
Itoh: Molecular cloning of eel growth hormone cDNA and its expression in Escherichia coli. Gene, 73, 545-551 (1988).

5) B. Funkenstein, T, T. Chen, D. A. Powers, and B. Carari: Cloning and sequencing of the gilthead seabream (Sparus aurata) growth hormone-encoding cDNA. Gene, 103, 243-247 (1991).

6) L. Agellon and T. T. Chen: Rainbow trout growth hormone: molecular cloning of CDNA and expression on Escherichia coli. DNA, 5, 463-471 (1986),

7) H. Momota, R. Kosugi, H. Hiramatsu, H. Ohgai, A. Hata, and H. Ishioka: Nucleotide sequence of CDNA the pregrowth hormone of red seabream (Pagrus major). Nucleic Acids Res., 16, 3107 (1988).

8) F. Rentier-Delrue, D. Swennen, J. C. Philippart, C. Lhoir, M. Lion, O. Benrubi, and J. A. Martial: Tilapia growth hormone molecular cloning of CDNA and expression in Escherichia coll. DNA, 8, 271-278 (1989).

9) N. Sato, K. Watanabe, K. Murata, M. Sakaguchi, Y. Kariya, S. Kimura, M. Nonaka, and A. Kimura: Molecular cloning and nucleotide sequence of tuna growth hormone cDNA. Biochim. Biophys. Acta, 949, 35-42 (1988).

10) H. J. Tsai, K. L. Lin, and T. T. Chen: Molecular cloning and expression of yellowfin porgy (Acanthopagrus latus Houttuyn) growth hormone cDNA. Comp. Biochem. Physiol., 104B, 803-810 (1993).

11) M. Watahiki, M. Tanaka, N. Masuda, M. Yamakawa, Y. Yoneda, and $K$. Nakashima: cDNA cloning and primary structure of yellowtail (Seriora quinqueradiata) pregrowth hormone. Gen. Comp. Endocrinol, 70, 401-406 (1988).

12) N. Sato, M. Sakaguchi, M. Nonaka, K. Murata, K. Watanabe, T. Hayami, Y, Karita, A. Kimura, and S. Kimura: EXpression of the tuna growth hormone cDNA in Escherichia coli. Appl. Microbiol. Biotechnol., 30, 153-159 (1989).

13) H. J. Tsai and C.F. Tseng: Expression of rainbow trout growth hormone cDNA in Escherichia coll from vector utilizing tac promoter. J. Fish. Soc. Taiwan, 19, 45-53 (1992).

14) T. Hayami, Y. Inoue, T. Ichiryu, A. Kimura, M. Nonaka, N. Sato, and K. Murata: Production of recombinant tuna growth hormone by a yeast, Saccharomyces cerevisiae. Agric. Biol. Chem., 53, 2917-2922 (1989).

15) H. J. Tsai, C. F. Tseng, and T. T. Kuo: Expression of ranbow trout growth hormone cDNA in yeast. Bull. Inst. Zool. Acad. Sinica, 32, 162-170 (1993).

16) J. L. Kuo and H. J. Tsai: Electrophoretic analysis of recombinant fish growth hormone secreted from Saccharomyces cerevisiae by using $a$-factor-leader sequence. J. Fish. Soc. Taiwan, 20, 51-58 (1993),

17) D. V. Goeddel: Systems for heterologous gene expression, in "Method in Enzymology" (ed. by D. V. Goeddel), Vol. 185, Academic Press, New York, 1990, pp. 3-7.

18) A. B. Rose and J. R. Broach: Propagation and expression of cloned gene in yeast: $2 \mu \mathrm{m}$ circle-based vectors, in "Methods in Enzymology" (ed. by D. V. Goedde!), Vol. 185, Academic Press, New York, 1990, pp. 234-279.

19) G. E. Smith and M. D. Summer: Analysis of baculovirus genomes with restriction endonucleases. Virology, 89, 517527 (1978).

20) C. J. Huang, F. L. Huang, G. D. Chang, Y. S. Chang, C. F. Lo, M. J. Fraser, and T. B. Lo: Expression of two forms of carp gonadotropin $\alpha$ subunit in insect cells by recombinant baculovirus. Pro. Natl. Acad. Sci. USA, 88, 7486-7490 (1991).

21) M. D. Summer and G. E. Smith: A manual of methods for baculovirus yectors and insect cell culture procedures. Tex. Agric. Exp. Stn. Bull. No. 1555, 1987, pp. 1-56.

22) B. G. Corsaro and M. J. Fraser: Transfection of lepidopteran insect cells with baculovirus DNA. J. Tissue Culture
Methods, 12, 7-11, (1988)

23) M. A. Innis and D. H. Gelfand: Optimization of PCRs, in "PCR Protocols" (ed. by M. A. Innis, D. H. Gelfand, J. J. Sninsky, and T.J. Hite), Academic Press, San Diego, 1990, pp. 1-12.

24) F. Sanger, S. Nicklen, and A. R, Coulson: DNA sequencing with chain terminating inhibitor. Pro. Natl. Acad. Sci. USA, 74, 5463-5467 (1977)

25) P. L. Yang: The influence of the nucleotide sequences near the translation start and termination site of Hepatitis $B$ surface antigen gene on the gene expression level in the baculovirus expression vector system. Master thesis, Graduate School of Biology, Fu-Jen Catholic University, Tajpei, Taiwan, 1991.

26) J. P. Burand, M. D. Summer, and G. F. Smith: Transfection with baculovirus DNA. Virology, 101, 286-290 (1980).

27) E. B. Carstens, S. T. Tjia, and W. Doerfer: Infection DNA from Autographa californica nuclear polyhedrosis virus. Virology, 101, 311-314 (1980).

28) J. Pen, G. W. Welling, and S. W. Wester: An efficient procem dure for the isolation of recombinant baculovirus. Nucleic Acid Res., 17, 451 (1989).

29) E. Southern: Detection of specific sequences among DNA fragments separated by gel electrophoresis. J. Mol. Biol., 98, 503-517 (1975).

30) B. D. Hames: One-dimensional polyacrylamide gel, in "Gel Electrophoresis of Proteins" (ed. by B. D. Hames and D. Richwood), Oxford University Press, New York, 1990, pp. $30-50$.

31) C. R. Merril, D. Goldman, S. A. Sedman, and M. L. Ebert: Ultra-sensitive strain for proteins in polyacrylamide gels shows regional variation in cerebrospinal fluid proteins. Science, 211, 1437-1438 (1981).

32) H. Towbin, T, Staehelin, and J. Gordon: Electrophoretic transfer of proteins from polyacrylamide gels to nitrocellulose sheets: procedure and some applications. Proc. Natl. Acad. Sci. USA, 76, 4350-4354 (1976).

33) B. Maiorella, D. Inlow, A. Shauger, and D. Harano: Largescale insect cell-culture for recombinant protein production. Biotechnology, 6, 1406-1410 (1988).

34) H. Kawauchi, S. Moriuama, A. Yasuda, K. Yamaguchi, K. Shirabata, J. Kubota, and T. Hirano: Isolation and characterization of chum salmon growth hormone. Arch. Biochem Biophys., 244, 542-552 (1986).

35) T. Noso, A. Yasuda, I. Kawazoe, A. Takehara, K. Sakai, and H. Kawauchi: Isolation and characterization of growth hormone from a marine fish, bonito (Katsuonus pelamis). Int. J. Pept. Protein Res, 32, 579-589 (1988).

36) B. G. Ooi, C. Rankin, and L. K. Miller: Downstream sequences augment transcription from the essential initiation site of a baculovirus polyhedrin gene. J. Mol. Biol., 210 , $721-736$ (1989).

37) L. J. Zhao, K. Irie, T. Trirawatanapong, R. Nakano, A. Nakashima, M. Morimatsu, and R. Padmanabhan: Synthesis of biologically active adenovirus preterminal protein in insect cells using a baculovirus vector. Gene, 100, 147-154 (1991).

38) A. V. Luckow and M. D. Summers: Trends in the development of baculovirus expression vectors. Biotechnology, 6 , 47-55 (1988).

39) C. A. Chariton and L. E. Volkman: Effect of tunicamycin on the structural proteins and infectivity of budded Awtographe californica nuclear polyhedrosis virus. Virology, 154, 214 218 (1986).

40) L. B. Agellon, C. J. Emery, J. M. Jones, S. L. Davies, A. D. Dingle, and T.T. Chen: Promotion of rapid growth of rainbow trout (Salmo gairdneri) by a recombinant fish growth hormone, Can. J. Fish. Aquat, Sci. 45, 146-151 (1988). 